\title{
Influence of methionine supplementation of growing diets enriched with lysine on feedlot performance and characteristics of digestion in Holstein steer calves
}

\author{
Noemí Torrentera', Ramsés Carrasco ${ }^{1}$, Jaime Salinas-Chavira ${ }^{2}$, Alejandro Plascencia ${ }^{1, *}$, and Richard A. Zinn ${ }^{3}$
}

\footnotetext{
* Corresponding Author: Alejandro Plascencia Tel: +52-686-5636906(111), Fax: +52-686-5636907, E-mail: aplas_99@yahoo.com

'Research Institute of Veterinary Sciences, UABC, Mexicali, Baja California 21100, México

2 PVeterinary and Animal Science School, UAT, Cd. Victoria, Tamaulipas 87000, México

${ }^{3}$ Department of Animal Science, University of

California, Davis CA95616, USA
}

Submitted Mar 4, 2016; Revised Jun 13, 2016; Accepted Jul 11, 2016
Objective: Two trials were conducted in order to examine the effects of level of supplemental methionine on productive performance, dietary energetic, plasma amino acid concentration, and digestive function.

Methods: Dietary treatments consisted of a steam-flaked corn-based diet containing urea as the only source of supplemental nitrogen supplemented with no supplemental amino acid (control), or control plus $1.01 \%$ lysine and $0.032 \%, 0.064 \%, 0.096 \%$, or $0.128 \%$ methionine. In Trial 1, 150 Holstein steer calves $(127 \pm 4.9 \mathrm{~kg})$ were utilized to evaluate the influence of treatments on growth-performance, dietary energetic, plasma amino acid concentration during the first 112 days of growing period. During the initial 56-d period calves received the 5 experimental diets. During the subsequent $56-\mathrm{d}$ period all calves were fed the control diet.

Results: During the initial 56-d period, methionine supplementation increased (linear effect, $\mathrm{p}<0.01)$ plasma methionine. In the presence of supplemental lysine, increases on level of methionine in diet did not affect average daily gain. However, increased gain efficiency (quadratic effect, $\mathrm{p}$ $=0.03$ ) and estimated dietary net energy (NE; linear effect, $\mathrm{p}=0.05)$. Estimated metabolizable methionine supply was closely associated $\left(\mathrm{R}^{2}=0.95\right)$ with efficiency NE utilization for maintenance and gain. During the subsequent 56-d period, when all calves received the control diet (no amino acid supplementation), plasma amino acid concentrations and growth performance was not different among groups. However, the effects of methionine supplementation during the initial 56-period carried over, so that following a 56-d withdrawal of supplementation, the overall 112-d effects on gain efficiency (quadratic effect, $\mathrm{p}=0.05$ ) dietary $\mathrm{NE}$ (linear effect, $\mathrm{p} \leq 0.05$ ) remained appreciable. In Trial 2, 5 cannulated Holstein steers were used to evaluate treatment effects on characteristics of digestion and amino acid supply to the small intestine. There were no treatment effects on flow of dietary and microbial $\mathrm{N}$ to the small intestine. Postruminal $\mathrm{N}$ digestion increased $(\mathrm{p}=0.04)$ with increasing level of supplemental methionine. Methionine supplementation linearly increased $(\mathrm{p}<0.01)$ duodenal flow of methionine. Likewise, lysine supplementation increased an average of $4.6 \%(\mathrm{p}=0.04)$ duodenal flow of lysine. In steers that received nonsupplemented diet, observed intestinal amino acid supply were in good agreement with expected. Conclusion: We conclude that addition of rumen-protected methionine and lysine to diets may enhance gain efficiency and dietary energetics of growing Holstein calves. Observed amino acid supply to the small intestine were in good agreement with expected, supportive of NRC (2000, Level 1).

Keywords: Holstein, Feedlot, Amino Acid Supplementation, Performance, Digestion

\section{INTRODUCTION}

Commonly, in the Southwestern of United States and in Northern of Mexico, the Holstein and other breeds calves are fed during growing and finishing with corn-based diets, either

\section{www.ajas.info}


rolled or steam flaked. These diets contain about $12 \%$ to $13 \%$ of crude protein, and adding urea as non-protein nitrogen source (NNP) [1,2]. Theoretically, these diets satisfy the requirements of metabolizable amino acids during the total feeding (around 350 days) [3], but these diets do not fulfill those requirements during the early stages of growth (first 112 to 140 days) [4].

Deficiencies in essential amino acids in early stages of growing phase have shown negatively influence on average daily gain (ADG) and dry matter intake causing economic losses $[5,6]$. Research on the estimation of amino acids requirement and nitrogen retention in growing cattle have methionine as the primary limiting amino acid, while the second is lysine $[1,5]$. With few exceptions (ie. fishmeal), native protein supplements commonly fed to feedlot cattle (ie. oilseed meals, distillers grains) are not good sources of metabolizable methionine, and/or are deficient in lysine [6]. Very little research has been reported that evaluates optimal levels of methionine supplementation as a single ruminally protected amino acid in practical feedlot diets that are expected to otherwise meet amino acid requirements. The objective of the present study was to evaluate the influence of rumen-protected methionine supplementation levels on early growth-performance of calf-fed Holstein steers fed a conventional steam-flaked corn-based growing diet containing urea as the only source of supplemental nitrogen.

\section{MATERIALS AND METHODS}

Animal care and handling techniques were approved by the University of California Animal Care and Use Committee.

\section{Trial 1. Feedlot growth performance and plasma amino} acid concentration

One hundred and fifty Holstein steer calves $(127 \pm 4.9 \mathrm{~kg})$ were utilized to evaluate the influence of supplemental methionine on growth performance, dietary energetics, and plasma amino acid concentration during the initial 112-d feedlot growing phase. Calves were obtained from a commercial calf ranch (CalfTech, Tulare, CA, USA), and were $119 \pm 4 \mathrm{~d}$ of age. Upon arrival at the University of California Desert Research and Extension Center (El Centro, CA, USA), steer calves were vaccinated against infectious bovine rhinotracheitis, bovine viral diarrhoea (type 1 and 2), parainfluenza 3, bovine respiratory syncytial virus (Cattle Master Gold FP 5 L5, Pfizer Animal Health, New York, NY, USA), clostridia (Ultrabac 8, Pfizer Animal Health, USA), treated against internal and external parasites (Dectomax, Pfizer Animal Health, USA), injected with 1,500 IU vitamin E (as d-alpha-tocopherol) 500,000 IU vitamin A (as retinyl-palmitate) and 50,000 IU vitamin $\mathrm{D}_{3}$ (Vital E-AD, Stuart Products, Bedford, TX, USA), and $300 \mathrm{mg}$ tulathromycin (Draxxin, Pfizer Animal Health, USA). Steers calves were blocked by initial shrunk (off truck) weight into five groups and randomly assigned within weight groupings to 30 pens (five steers per pen). Pens were $43 \mathrm{~m}^{2}$ with $22 \mathrm{~m}^{2}$ overhead shade, automatic waterers and $2.4 \mathrm{~m}$ fence-line feed bunks. Steers were allowed itum access to feed and water. Fresh feed was provided twice daily at 06:00 and 14:00 h, offering approximately $40 \%$ of daily consumption in the morning feeding and the remainder in the afternoon feeding. Composition of experimental diets are shown in Table 1. The basal diet utilized urea as the only source of supplemental nitrogen. During the initial 56-d period, five dietary treatments were evaluated: i) no amino acid supplementation; ii) $0.032 \%$ methionine $+1.01 \%$ lysine; iii) $0.064 \%$ methionine $+1.01 \%$ lysine, iv) $0.096 \%$ methionine $+1.01 \%$ lysine; and v) $0.128 \%$ methionine $+1.01 \%$ lysine. The percentage of amino acids included in dietary treatments were as percentage of dietary dry matter. The source of supplemental methionine was Smartamine (Adisseo, Alpharetta, GA, USA). The source of supplemental lysine was AminoShure (Balchem; Animal Nutrition \& Health, New Hampton, NY, USA). From day 56 through day 112, all steers received the basal diet with no supplemental amino acids. Blood samples from jugular vein were obtained (one steer per pen/six steers per treatment) at days 56 and 112 of the trial. Blood samples were collected via venipuncture of the jugular vein into heparinized sterile vacuum blood collection tubes (Becton Dickinson, Franklin Lakes, NJ, USA). Following collection, samples were immediately placed in ice. Blood samples were centrifuged for $5 \mathrm{~min}$ at $1,500 \times \mathrm{g}$. Plasma was stored at $-20^{\circ} \mathrm{C}$.

Energy gain (EG, Mcal/d) was calculated by the equation: $\mathrm{EG}=0.0557 \mathrm{~W}^{0.75} \times \mathrm{ADG}^{1.097}$; where $\mathrm{EG}$ is the daily deposited energy, and $\mathrm{W}$ is the body weight [7]. Maintenance energy (ME, Mcal/d) was calculated by the equation: $\mathrm{ME}=0.084 \mathrm{~W}^{0.75}$ [8]. From the derived estimates of energy required for maintenance and gain, the net energy of maintenance $\left(\mathrm{NE}_{\mathrm{m}}\right)$ and gain $\left(\mathrm{NE}_{\mathrm{g}}\right)$ values of the diet were obtained using the quadratic formula:

$$
x=\left(-\mathrm{b}-\sqrt{b^{2}-4 a c}\right) / 2 \mathrm{c}
$$

Where $x=$ diet $\mathrm{NE}_{\mathrm{m}}, \mathrm{Mcal} / \mathrm{kg}, \mathrm{a}=-0.41 \mathrm{ME}, \mathrm{b}=0.877 \mathrm{ME}$ +0.41 dry matter intake (DMI) $+\mathrm{EG}$, and $\mathrm{c}=-0.877 \mathrm{DMI}$, and $\mathrm{NE}_{\mathrm{g}}=0.877 \mathrm{NE}_{\mathrm{m}}-0.41$ [4].

Data for growth performance variables were analyzed in a randomized complete block design, considering initial shrunk weight groupings for blocks, and pen as experimental unit [9], according to the following statistical model: $Y_{i j}=\mu+B_{i}+T_{j}+\varepsilon_{i j}$, where $\mu$ is the common experimental effect, $B_{i}$ represents initial weight block effect, $T_{j}$ represents dietary treatment effect, and $\varepsilon_{\text {ii }}$ represents the residual error. In determination of ADG, interim and final weights were reduced $4 \%$ to account for digestive tract fill. Plasma amino acid concentration was analyzed using the repeated measures option of Proc MIXED [9], using the data 
Table 1. Ingredients and composition of experimental basal diets fed to steers (Trial 1 and 21)

\begin{tabular}{|c|c|c|c|c|c|}
\hline \multirow{2}{*}{ Item } & \multicolumn{5}{|c|}{ Supplemental methionine level ( $\%$ of dietary DM) } \\
\hline & 0 & 0.032 & 0.064 & 0.096 & 0.128 \\
\hline \multicolumn{6}{|c|}{ Ingredient composition (\%, DM basis) } \\
\hline Steam-flaked corn & 74.95 & 73.91 & 73.88 & 73.84 & 73.81 \\
\hline Sudan grass hay & 7.68 & 7.68 & 7.68 & 7.68 & 7.68 \\
\hline Alfalfa hay & 3.84 & 3.84 & 3.84 & 3.84 & 3.84 \\
\hline Tallow & 3.09 & 3.09 & 3.09 & 3.09 & 3.09 \\
\hline Molasses & 7.37 & 7.37 & 7.37 & 7.37 & 7.37 \\
\hline Magnesium oxide & 0.18 & 0.18 & 0.18 & 0.18 & 0.18 \\
\hline Dicalcium phosphate & 0.49 & 0.49 & 0.49 & 0.49 & 0.49 \\
\hline Limestone & 1.22 & 1.22 & 1.22 & 1.22 & 1.22 \\
\hline Urea & 0.88 & 0.88 & 0.88 & 0.88 & 0.88 \\
\hline Trace mineral salt't) & 0.30 & 0.30 & 0.30 & 0.30 & 0.30 \\
\hline Smartamine $^{3)}(\%)$ & 0 & 0.032 & 0.064 & 0.096 & 0.128 \\
\hline Aminoshure $^{4)}(\%)$ & 0 & 1.01 & 1.01 & 1.01 & 1.01 \\
\hline \multicolumn{6}{|c|}{ Nutrient composition (DM basis) } \\
\hline \multicolumn{6}{|l|}{ Net energy (Mcal/kg) } \\
\hline Maintenance & 2.21 & 2.21 & 2.21 & 2.21 & 2.21 \\
\hline Gain & 1.55 & 1.55 & 1.55 & 1.55 & 1.55 \\
\hline Crude protein (\%) & 11.5 & 12.2 & 12.2 & 12.3 & 12.3 \\
\hline Ether extract (\%) & 6.51 & 6.51 & 6.51 & 6.51 & 6.51 \\
\hline $\operatorname{NDF}(\%)$ & 13.25 & 13.25 & 13.25 & 13.25 & 13.25 \\
\hline Calcium (\%) & 0.73 & 0.73 & 0.73 & 0.73 & 0.73 \\
\hline Phosphorus (\%) & 0.36 & 0.36 & 0.36 & 0.36 & 0.36 \\
\hline Potassium (\%) & 0.79 & 0.79 & 0.79 & 0.79 & 0.79 \\
\hline Magnesium (\%) & 0.28 & 0.28 & 0.28 & 0.28 & 0.28 \\
\hline Sulfur (\%) & 0.16 & 0.1 & 0.16 & 0.16 & 0.16 \\
\hline
\end{tabular}

DM, dry matter; NDF, neutral detergent fiber.

${ }^{1)}$ Chromic oxide (0.35\%) was added as digesta marker in Exp 2.

${ }^{2)}$ Trace mineral salt contained: $\mathrm{CoSO}_{4}, 0.068 \%$; $\mathrm{CuSO}_{4}, 1.04 \% ; \mathrm{FeSO}_{4}, 3.57 \% ; \mathrm{ZnO}, 1.24 \% ; \mathrm{MnSO}_{4}, 1.07 \%, \mathrm{KI} 0.052 \%$, and $\mathrm{NaCl}, 92.96 \%$.

${ }^{3)}$ Supplemental Smartamine (as \% of dietary DM): Treatment $1=0 \%$; treatment $2=0.032 \%$; treatment $3=0.064 \%$; treatment $4=0.096 \%$, and treatment $5=0.128 \%$ ).

4) Supplemental Aminoshure: Treatment $1=0 \%$; treatments 2, 3, 4, and $5=1.01 \%$.

${ }^{5)}$ Calculated based on tabular values expressed for individual feed ingredients (NRC [3]).

from each steer. The effects of increasing levels of methionine in the diet were tested for linear and quadratic components by means of orthogonal polynomials. Data were analyzed using the MIXED procedure [9].

\section{Trial 2. Characteristics of digestion}

Five Holstein steers $(188 \pm 7.15 \mathrm{~kg})$ with cannulas in rumen and proximal duodenum [10] were used in a $5 \times 5$ Latin square design to evaluate treatment effects on digestive function and on amino acid supply to intestine. Calves were $180 \pm 9 \mathrm{~d}$ of age. Treatments were the same as corresponding diets used in Trial 1 with inclusion of $0.3 \%$ chromic oxide as an indigestible marker to estimate nutrient flows and digestibility. Chromic oxide was premixed with minor ingredients (urea, limestone and trace mineral salt) before incorporation into complete mixed diets. Steers were housed (indoor facilities) in individual pens (4 $\mathrm{m}^{2}$ ) with concrete floor covered by neoprene carpet, automatic waterers and individual feed bunk. Experimental diets were fed daily in equal portions at 08:00 and 20:00 h. Dry matter intake was restricted to $2.2 \%$ of the body weight. Experimental periods consisted of $10 \mathrm{~d}$ for diet adjustment and $4 \mathrm{~d}$ for sample collection. During collection, duodenal and fecal samples were taken twice daily as follows: $\mathrm{d} \mathrm{1,} \mathrm{10:30} \mathrm{and} \mathrm{16:30;} \mathrm{d}$ 2, 09:00 and 15:00; d 3, 07:30 and 15:00; and d 4, 06:00 and 12:00. Individual samples consisted of approximately $700 \mathrm{~mL}$ of duodenal chyme and $200 \mathrm{~g}$ (wet basis) of fecal material. Samples for each steer within each collection period were composited for analysis. Upon completion of the experiment, ruminal fluid was obtained via the ruminal cannula from all steers and composited for isolation of ruminal bacteria via differential centrifugation [11]. Feed, duodenal fluid and fecal samples were subjected to the following analysis according to AOAC [12]: dry matter (DM, oven drying at $105^{\circ} \mathrm{C}$ until no further weight loss method 930.15); ash (method 942.05), Kjeldahl N (method 984.13), and neutral detergent fiber (NDF) [13] corrected for NDF-ash, incorporating heat stable $\alpha$-amylase ([Ankom FAA, Ankom Technology, Macedon, NY, USA] at $1 \mathrm{~mL}$ per $100 \mathrm{~mL}$ of NDF solution]; chromic oxide [14]; and starch [15]. Duodenal samples were analyzed for ammonia $\mathrm{N}$ (method 941.04) [12] and purines [16]. Duodenal flow and fecal excretion of DM were calculated 
based on marker ratio, using chromic oxide. Microbial organic matter (MOM) and $\mathrm{N}(\mathrm{MN})$ leaving the abomasum was calculated using purines as a microbial marker [16]. Organic matter $(\mathrm{OM})$ fermented in the rumen was considered equal to $\mathrm{OM}$ intake minus the difference between the amount of total OM reaching the duodenum and MOM reaching the duodenum. Feed $\mathrm{N}$ escape to the small intestine was considered equal to total $\mathrm{N}$ leaving the abomasum minus ammonia- $\mathrm{N}, \mathrm{MN}$ and endogenous $\mathrm{N}\left(0.195 \times \mathrm{BW}^{0.75}\right)$ [17].

The experimental design for this experiment was a $5 \times 5$ Latin square. Statistical data were analyzed using the MIXED procedure of SAS [9]. Fixed effects consisted of treatments, and random effects consisted of steers and period. The statistical model for the trial was as follows:

$$
Y_{i j k}=\mu+L_{i}+P_{j}+T_{k}+E_{i j k}
$$

Where, $Y_{i \mathrm{ik}}$ is the response variable, $\mu$ is the common experimental effect, $L_{i}$ is the steer effect, $P_{j}$ is the period effect, $T_{k}$ is the treatment effect and $\mathrm{E}_{\mathrm{ijk}}$ is the residual error. The effects of increasing levels of methionine in diet were tested for linear and quadratic components by means of orthogonal polynomials.

\section{RESULTS AND DISCUSSION}

Treatment effects on growth performance and dietary net energy (NE) are shown in Table 2. During the initial 56-d period, methionine supplementation did not affect ADG ( $p=0.27)$, however, it increased gain efficiency (quadratic effect, $p=0.03$ ) and estimated dietary NE (linear effect, $\mathrm{p}=0.05$ ). As expected, during the subsequent $56-\mathrm{d}$ period, when all calves received the same basal diet (no amino acid supplementation), growth performance was not different $(\mathrm{p}>0.20)$ among experimental

Table 2. Treatment effects on growth performance and dietary energetics of feedlot steers (Trial 1)

\begin{tabular}{|c|c|c|c|c|c|c|c|c|}
\hline \multirow{2}{*}{ Item } & \multicolumn{5}{|c|}{ Supplemental methionine level ( $\%$ of dietary DM) } & \multirow{2}{*}{ SEM } & \multicolumn{2}{|c|}{ Contrast $p$-value } \\
\hline & 0 & 0.032 & 0.064 & 0.096 & 0.128 & & Linear & Quadratic \\
\hline Days on test & 112 & 112 & 112 & 112 & 112 & & & \\
\hline Pen replicates & 6 & 6 & 6 & 6 & 6 & & & \\
\hline \multicolumn{9}{|l|}{ Weight (kg) } \\
\hline Initial & 120 & 120 & 120 & 120 & 120 & 0.1 & 0.32 & 0.16 \\
\hline Final & 259 & 261 & 260 & 262 & 258 & 2.2 & 0.99 & 0.34 \\
\hline \multicolumn{9}{|l|}{ ADG $(\mathrm{kg})$} \\
\hline $1-56 d$ & 1.13 & 1.17 & 1.17 & 1.18 & 1.16 & 0.02 & 0.27 & 0.21 \\
\hline $56-112 d$ & 1.35 & 1.34 & 1.34 & 1.34 & 1.30 & 0.03 & 0.40 & 0.63 \\
\hline $1-112 d$ & 1.24 & 1.25 & 1.25 & 1.26 & 1.23 & 0.02 & 0.95 & 0.31 \\
\hline \multicolumn{9}{|l|}{ DMI (g/d) } \\
\hline $1-56 d$ & 4.50 & 4.52 & 4.39 & 4.33 & 4.46 & 0.09 & 0.35 & 0.40 \\
\hline $56-112 d$ & 5.56 & 5.48 & 5.35 & 5.40 & 5.40 & 0.10 & 0.23 & 0.37 \\
\hline $1-112 d$ & 5.03 & 5.00 & 4.87 & 4.87 & 4.93 & 0.09 & 0.26 & 0.36 \\
\hline \multicolumn{9}{|l|}{ ADG/DMI } \\
\hline $1-56 d$ & 0.251 & 0.260 & 0.267 & 0.273 & 0.261 & 0.005 & 0.03 & 0.03 \\
\hline $56-112 d$ & 0.242 & 0.243 & 0.251 & 0.249 & 0.241 & 0.005 & 0.87 & 0.19 \\
\hline $1-112 d$ & 0.246 & 0.251 & 0.258 & 0.259 & 0.250 & 0.004 & 0.24 & 0.05 \\
\hline \multicolumn{9}{|c|}{ Dietary net energy (Mcal/kg) } \\
\hline \multicolumn{9}{|l|}{ Maintenance } \\
\hline $1-56 d$ & 1.78 & 1.81 & 1.85 & 1.89 & 1.83 & 0.03 & 0.05 & 0.05 \\
\hline $56-112 d$ & 2.06 & 2.09 & 2.14 & 2.13 & 2.08 & 0.03 & 0.47 & 0.13 \\
\hline $1-112 d$ & 1.95 & 1.98 & 2.02 & 2.04 & 1.98 & 0.03 & 0.21 & 0.07 \\
\hline \multicolumn{9}{|l|}{ Gain } \\
\hline $1-56 d$ & 1.15 & 1.18 & 1.21 & 1.25 & 1.19 & 0.02 & 0.04 & 0.05 \\
\hline $56-112 d$ & 1.40 & 1.42 & 1.47 & 1.46 & 1.42 & 0.03 & 0.47 & 0.13 \\
\hline $1-112 d$ & 1.30 & 1.32 & 1.36 & 1.38 & 1.32 & 0.02 & 0.21 & 0.07 \\
\hline \multicolumn{9}{|c|}{ Observed/expected dietary net energy } \\
\hline \multicolumn{9}{|l|}{ Maintenance } \\
\hline $1-56 d$ & 0.818 & 0.835 & 0.853 & 0.870 & 0.841 & 0.012 & 0.04 & 0.05 \\
\hline $56-112 d$ & 0.951 & 0.962 & 0.986 & 0.983 & 0.960 & 0.016 & 0.47 & 0.13 \\
\hline $1-112 d$ & 0.898 & 0.910 & 0.931 & 0.938 & 0.911 & 0.013 & 0.21 & 0.07 \\
\hline \multicolumn{9}{|l|}{ Gain } \\
\hline $1-56 d$ & 0.768 & 0.790 & 0.813 & 0.835 & 0.798 & 0.015 & 0.04 & 0.05 \\
\hline $56-112 d$ & 0.938 & 0.952 & 0.981 & 0.979 & 0.948 & 0.021 & 0.47 & 0.13 \\
\hline $1-112 d$ & 0.870 & 0.886 & 0.913 & 0.922 & 0.886 & 0.017 & 0.21 & 0.07 \\
\hline
\end{tabular}

$D M$, dry matter; SEM, standard error of the mean; ADG, average daily gain. 
group. However, the effects of methionine supplementation during the initial 56-period carried over, so that following a 56-d withdrawal of supplementation, the overall 112-d effects on gain efficiency (quadratic effect, $\mathrm{p}=0.05$ ) and dietary NE (linear effect, $\mathrm{p} \leq 0.05$ ) remained appreciable. Improved gain efficiency and dietary NE are the more consistent responses in growth performance with improved metabolizable amino acid nutrition [1].

During this early feedlot growing phase, metabolizable methionine is expected to be the first limiting amino acid in calves fed a steam-flaked corn-based diets with urea as the sole source of supplemental N. Based on NRC [3] the metabolizable methionine and lysine requirements of a steer with an average weight of $190 \mathrm{~kg}$ and an ADG of $1.24 \mathrm{~kg}$ are 9.6 and $30.6 \mathrm{~g} / \mathrm{d}$, respectively. These estimates correspond closely to requirements of 10.2 and $32.7 \mathrm{~g} / \mathrm{d}$, respectively, using empirically derived equations of Zinn and Shen [4]. Based on observed DMI (5.31 $\mathrm{kg} / \mathrm{d}$ ), the corresponding expected metabolizable methionine and lysine supply [3] to steers in this study are 8.2 and $27.0 \mathrm{~g} / \mathrm{d}$, respectively.

As has been demonstrated in previous studies [1,17], DMI by feedlot calves reflects and attempt to consume not only suf- ficient energy, but also sufficient amounts of essential amino acids to sustain their genetic potential for growth. Indeed, the low observed dietary NEm and NEg ( $87 \%$ and $84 \%$ of expected, respectively) is consistent with previous studies where the metabolizable amino acid supplies were inadequate. Zinn et al. [1] observed that with a conventional steam-flaked corn-based growing-finishing diet (urea as sole source of supplemental N), supplementation of the diet (using fish meal) to provide estimated metabolizable amino acid requirements increased observed vs expected dietary NE from 0.87 to 0.97 .

Treatment effects on plasma amino acid concentrations are shown in Table 3. On d 56, methionine supplementation increased (linear effect, $\mathrm{p}<0.01$ ) plasma methionine and arginine. As a matter of convention in plasma amino acid analysis, a breakpoint is expected where level of limiting amino acid intake exceeds requirements $[18,19]$. That is, the inflection point at which plasma concentration begins to increase (breakpoint) is taken to indicate where metabolizable supply begins to exceed requirements. However, sampling convention may play a role in this generalization, as blood collection in these studies was conducted prefeeding. In contrast, Campbell et al. [20], with continual infusion of methionine into abomasum of steers fed

Table 3. Treatment effects on plasma indispensable amino acid profiles in Holstein steers (Trial 1)

\begin{tabular}{|c|c|c|c|c|c|c|c|c|}
\hline \multirow{2}{*}{ Item } & \multicolumn{5}{|c|}{ Supplemental methionine ( $\%$ of dietary DM) } & \multirow{2}{*}{ SEM } & \multicolumn{2}{|c|}{ Contrast $p$-value } \\
\hline & 0 & 0.032 & 0.064 & 0.096 & 0.128 & & Linear & Quadratic \\
\hline \multicolumn{9}{|c|}{ Plasma indispensable amino acid (mg/dL) } \\
\hline$d-56$ & 0.50 & 0.63 & 0.68 & 0.73 & 0.81 & 0.05 & $<0.01$ & 0.61 \\
\hline$d-112$ & 0.55 & 0.53 & 0.54 & 0.57 & 0.55 & 0.04 & 0.79 & 0.81 \\
\hline \multicolumn{9}{|l|}{ Lysine } \\
\hline \multicolumn{9}{|l|}{ Histidine } \\
\hline$d-56$ & 1.85 & 1.71 & 1.84 & 1.87 & 1.76 & 0.15 & 0.93 & 0.98 \\
\hline$d-112$ & 2.07 & 1.94 & 1.79 & 2.20 & 2.11 & 0.10 & 0.27 & 0.09 \\
\hline \multicolumn{9}{|c|}{ Phenylalanine } \\
\hline$d-56$ & 1.39 & 1.38 & 1.42 & 1.41 & 1.37 & 0.05 & 0.91 & 0.60 \\
\hline \multicolumn{9}{|l|}{ Leucine } \\
\hline$d-56$ & 2.34 & 2.43 & 2.35 & 2.35 & 2.24 & 0.13 & 0.50 & 0.51 \\
\hline$d-112$ & 2.61 & 2.68 & 2.61 & 2.83 & 2.75 & 0.14 & 0.35 & 0.97 \\
\hline \multicolumn{9}{|l|}{ Isoleucine } \\
\hline$d-56$ & 1.47 & 1.50 & 1.44 & 1.50 & 1.34 & 0.07 & 0.25 & 0.31 \\
\hline$d-112$ & 1.66 & 1.55 & 1.49 & 1.71 & 1.58 & 0.10 & 0.98 & 0.54 \\
\hline \multicolumn{9}{|l|}{ Valine } \\
\hline$d-56$ & 2.73 & 3.01 & 2.78 & 2.77 & 2.66 & 0.14 & 0.39 & 0.29 \\
\hline$d-112$ & 3.26 & 3.15 & 3.03 & 3.38 & 3.23 & 0.19 & 0.76 & 0.58 \\
\hline \multicolumn{9}{|l|}{ Arginine } \\
\hline$d-56$ & 2.60 & 2.99 & 2.90 & 2.85 & 3.27 & 0.16 & 0.03 & 0.87 \\
\hline
\end{tabular}

DM, dry matter; SEM, standard error of the mean. 
a methionine deficient diet, observed that both plasma methionine and $\mathrm{N}$ retention increased linearly with methionine infusion. There was also a numerical, but not statistically significant $(\mathrm{p}=0.22)$ increase in plasma lysine, possibly reflecting poor ruminal escape, as will be discussed later. There were no differences $(\mathrm{p}>0.20)$ in plasma amino acid concentrations at day 112 , as expected, as all calves had received the same basal diet during the second feeding period ( $\mathrm{d} 56$ to $\mathrm{d} 112$ ).

Treatment effects on characteristics of ruminal and total tract digestion are shown in Table 4. Surprisingly, there was a quadratic effect ( $p=0.03$ ) of amino acid supplementation on ruminal OM digestion, and a tendency for a quadratic effect on total tract OM digestion $(\mathrm{p}=0.10)$ and digestible energy $(\mathrm{p}=0.12)$. The basis for this effect is not certain. All treatments used the same basal diet, with amino acid treatments incorporated by top-dressing at time of feeding. There were no treatment effects $(\mathrm{p}>0.20)$ on flow of dietary and microbial $\mathrm{N}$ to the small intestine. Ruminal degradation of feed $\mathrm{N}$ averaged $69 \%$, in good agreement (109\%) with expected [3] based on diet formulation (63.3\%). In contrast, flow of microbial $\mathrm{N}$ to the small intestine was less (20\%) than expected based on NRC [3]. Postruminal $\mathrm{N}$ digestion increased (linear effect, $\mathrm{p}=0.04$ ) as dietary methionine level increased. Assuming an intestinal digestibility of $88 \%$ for methionine [21], the estimated contribution of the digestible $\mathrm{N}$ by the supplementary methionine can explain about $45 \%$ of the variation in postruminal $\mathrm{N}$ digestion.

Treatment effects on essential amino acid flow to the small intestine and plasma amino acid profiles are shown in Table 5 and 6. Methionine supplementation increased (linear effect, $\mathrm{p}<0.01)$ duodenal flow of methionine. Likewise, lysine supplementation appreciably increased $(4.6 \%, \mathrm{p}=0.04)$ duodenal flow of lysine, although the magnitude of the change was much smaller than anticipated. With respect to the basal non-supplemented diet, observed intestinal amino acid supply of methionine, histidine, phenylalanine, threonine, leucine, isoleucine, and valine were in good agreement with expected [3] averaging $98 \%, 107 \%, 110 \%, 105 \%, 103 \%, 100 \%$, and $90 \%$, respectively. In contrast, lysine flow to the small intestine was $120 \%$ of expected. By difference, intestinal supply of supple-

Table 4. Treatment effects on characteristics of ruminal and total tract digestion (Trial 2)

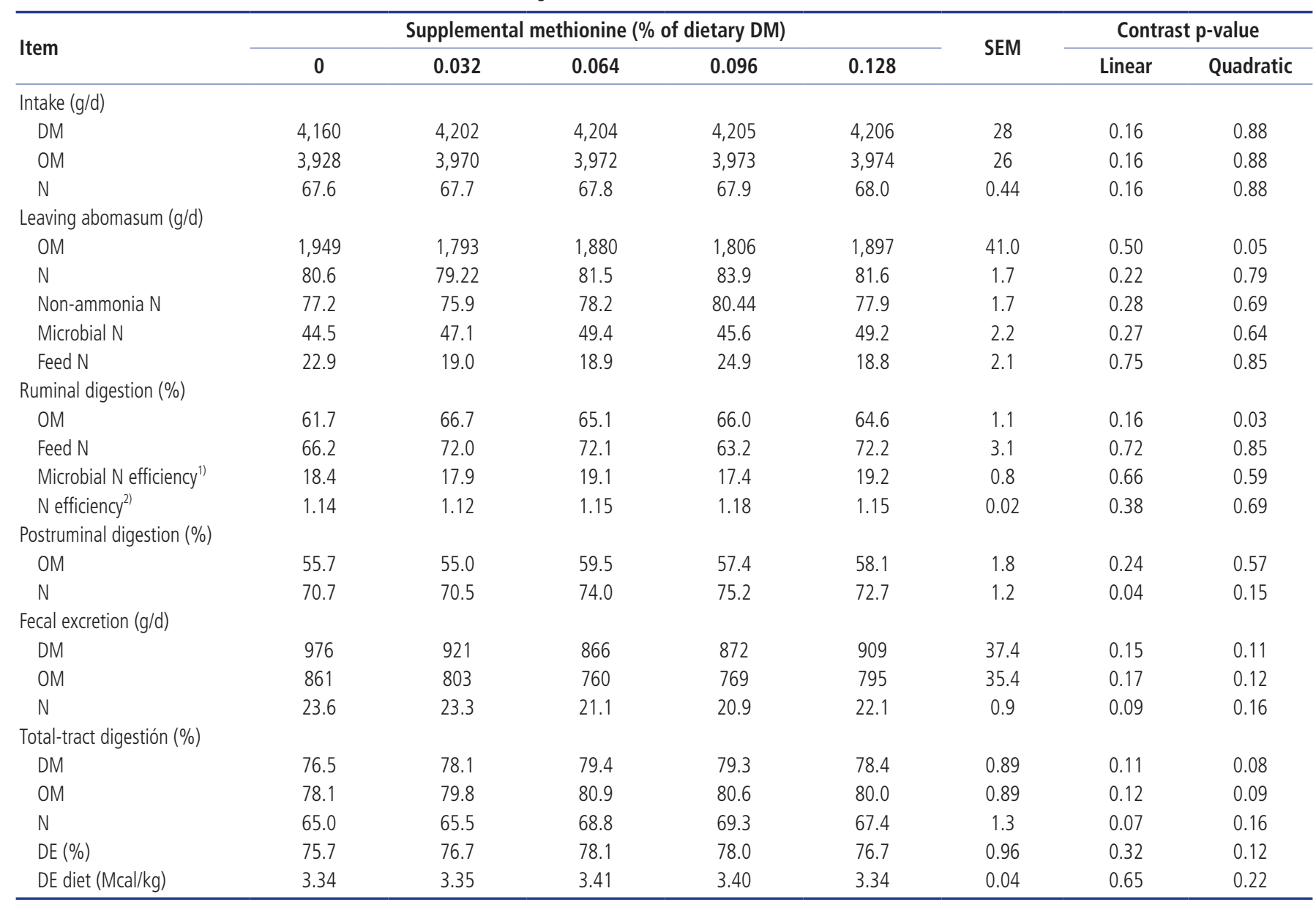

DM, dry matter; SEM, standard error of the mean; OM, organic matter; N, nitrogen; $\mathrm{DE}$, digestible energy.

1) Duodenal microbial $\mathrm{N}, \mathrm{g} / \mathrm{kg}$ OM fermented in the rumen.

${ }^{2)}$ Duodenal non-ammonia $\mathrm{N}, \mathrm{g} / \mathrm{g} \mathrm{N}$ intake. 
Table 5. Expected vs. observed supply of indispensable amino acids to the small intestine of Holstein steers (Trial 2).

\begin{tabular}{|c|c|c|c|c|c|c|c|c|}
\hline \multirow{2}{*}{ Item } & \multicolumn{5}{|c|}{ Supplemental methionine level ( $\%$ of dietary DM) } & \multirow{2}{*}{ SEM } & \multicolumn{2}{|c|}{ Contrast $p$-value } \\
\hline & 0 & 0.032 & 0.064 & 0.096 & 0.128 & & Linear & Quadratic \\
\hline \multicolumn{9}{|l|}{ Methionine } \\
\hline NRC [3] level 1 & 8.02 & 8.62 & 9.22 & 9.82 & 10.42 & & & \\
\hline Leaving abomasum & 7.63 & 7.95 & 8.35 & 8.62 & 8.33 & 0.2 & 0.01 & 0.12 \\
\hline \multicolumn{9}{|l|}{ Lysine } \\
\hline NRC [3] level 1 & 21.9 & 30.0 & 30.0 & 30.0 & 30.0 & & & \\
\hline Leaving abomasum & 26.4 & 27.5 & 28.3 & 27.6 & 27.3 & 0.6 & 0.28 & 0.06 \\
\hline \multicolumn{9}{|l|}{ Histidine } \\
\hline NRC [3] level 1 & 9.5 & 9.4 & 9.4 & 9.4 & 9.4 & & & \\
\hline Leaving abomasum & 9.1 & 8.9 & 8.9 & 9.4 & 9.2 & 0.3 & 0.56 & 0.72 \\
\hline \multicolumn{9}{|l|}{ Phenylalanine } \\
\hline NRC [3] level 1 & 21.6 & 21.3 & 21.3 & 21.3 & 21.3 & & & \\
\hline Leaving abomasum & 18.7 & 18.7 & 19.0 & 19.3 & 19.1 & 0.5 & 0.47 & 0.90 \\
\hline \multicolumn{9}{|l|}{ Threonine } \\
\hline NRC [3] level 1 & 22.0 & 21.8 & 21.8 & 21.8 & 21.8 & & & \\
\hline Leaving abomasum & 18.9 & 18.8 & 19.4 & 19.9 & 19.6 & 0.7 & 0.23 & 0.84 \\
\hline \multicolumn{9}{|l|}{ Leucine } \\
\hline NRC [3] level 1 & 42.8 & 42.0 & 42.0 & 42.0 & 42.0 & & & \\
\hline Leaving abomasum & 34.5 & 34.4 & 34.7 & 35.7 & 35.7 & 1.2 & 0.34 & 0.85 \\
\hline \multicolumn{9}{|l|}{ Isoleucine } \\
\hline NRC [3] level 1 & 21.6 & 21.3 & 21.3 & 21.3 & 21.3 & & & \\
\hline Leaving abomasum & 18.3 & 18.3 & 18.8 & 19.1 & 18.8 & 0.6 & 0.40 & 0.69 \\
\hline \multicolumn{9}{|l|}{ Valine } \\
\hline NRC [3] level 1 & 24.9 & 24.7 & 24.7 & 24.7 & 24.7 & & & \\
\hline Leaving abomasum & 20.0 & 19.8 & 20.1 & 21.3 & 20.7 & 0.7 & 0.23 & 0.97 \\
\hline \multicolumn{9}{|l|}{ Arginine } \\
\hline NRC [3] level 1 & 19.2 & 19.1 & 19.1 & 19.1 & 19.1 & & & \\
\hline Leaving abomasum & 17.2 & 17.1 & 17.0 & 18.1 & 17.2 & 0.7 & 0.62 & 0.89 \\
\hline
\end{tabular}

DM, dry matter; SEM, standard error of the mean; NRC, National Research Council.

mental methionine (Smartamine) and lysine (Aminosure) were $36 \%$ and $9 \%$ of intake, respectively. As expected, methionine supplementation increased plasma methionine concentration (linear effect, $\mathrm{p}=0.01$ ). However, consistent with the low ruminal escape of supplemental lysine, the small increase in plasma lysine with supplementation was not appreciable $(\mathrm{p}=0.47)$.

Metabolizable amino acid supply along with theoretical requirement [3] based on average growth rate of steers in Trial 1 are shown in Table 7. Metabolizable amino acid supplies were estimated according to Zinn and Owens [22]. Consistent with previous studies involving calf-fed Holstein steers [1], estimated metabolizable methionine supply in Trial 1 was closely associated $\left(R^{2}=0.95\right)$ with the efficiency of utilization of metabolizable energy for maintenance and gain (observed vs expected dietary $\mathrm{NE}$ ). During the subsequent 56-d period estimated metabolizable amino acid supply was similar for individual amino acids

Table 6. Treatment effects on plasma indispensable amino acid profiles in Holstein steers (Trial 2)

\begin{tabular}{|c|c|c|c|c|c|c|c|c|}
\hline \multirow{2}{*}{ Item } & \multicolumn{5}{|c|}{ Supplemental methionine ( $\%$ of dietary DM) } & \multirow{2}{*}{ SEM } & \multicolumn{2}{|c|}{ Contrast $p$-value } \\
\hline & 0 & 0.032 & 0.064 & 0.096 & 0.128 & & Linear & Quadratic \\
\hline \multicolumn{9}{|c|}{ Plasma indispensable amino acid (mg/dL) } \\
\hline Methionine & 0.42 & 0.41 & 0.46 & 0.56 & 0.63 & 0.03 & $<0.01$ & 0.07 \\
\hline Lysine & 0.97 & 1.09 & 1.06 & 1.11 & 1.02 & 0.12 & 0.76 & 0.47 \\
\hline Histidine & 1.76 & 1.55 & 1.57 & 1.71 & 1.61 & 0.10 & 0.52 & 0.22 \\
\hline Phenylalanine & 1.17 & 1.07 & 1.01 & 1.12 & 1.11 & 0.06 & 0.77 & 0.17 \\
\hline Threonine & 1.49 & 1.22 & 1.18 & 1.36 & 1.36 & 0.07 & 0.59 & 0.01 \\
\hline Leucine & 1.97 & 1.75 & 1.52 & 1.91 & 1.93 & 0.17 & 0.90 & 0.12 \\
\hline Isoleucine & 1.22 & 1.19 & 1.06 & 1.20 & 1.19 & 0.09 & 0.87 & 0.40 \\
\hline Valine & 2.56 & 2.25 & 2.04 & 2.40 & 2.36 & 0.16 & 0.60 & 0.09 \\
\hline Arginine & 1.90 & 1.79 & 1.75 & 2.04 & 1.88 & 0.16 & 0.68 & 0.72 \\
\hline
\end{tabular}

DM, dry matter; SEM, standard error of the mean. 
Table 7. Estimated supply versus requirements (NRC [3] Level 1) of metabolizable amino acids"1)

\begin{tabular}{|c|c|c|c|c|c|c|}
\hline \multirow{2}{*}{ Item } & \multicolumn{5}{|c|}{ Supplemental methionine level (\% of dietary DM) } & \multirow{2}{*}{$\begin{array}{l}\text { Requirement } \\
\text { (NRC [3]) }\end{array}$} \\
\hline & 0 & 0.032 & 0.064 & 0.096 & 0.128 & \\
\hline \multicolumn{7}{|c|}{ Metabolizable amino acid (g/d) } \\
\hline Methionine & 6.6 & 6.8 & 7.0 & 7.1 & 7.1 & 9.0 \\
\hline Lysine & 22.8 & 23.7 & 23.6 & 22.7 & 23.2 & 28.7 \\
\hline Arginine & 14.9 & 14.7 & 14.2 & 14.9 & 14.6 & 14.8 \\
\hline Isoleucine & 15.8 & 15.7 & 15.7 & 15.7 & 15.9 & 12.6 \\
\hline Valine & 17.3 & 17.0 & 16.8 & 17.5 & 17.6 & 17.9 \\
\hline Histidine & 7.9 & 7.7 & 7.4 & 7.7 & 7.8 & 11.2 \\
\hline Phenylalanine & 16.2 & 16.1 & 15.9 & 15.9 & 16.2 & 15.7 \\
\hline \multicolumn{7}{|l|}{ Period 56-112d } \\
\hline Leucine & 36.9 & 36.4 & 35.5 & 35.8 & 35.8 & 34.7 \\
\hline Isoleucine & 19.6 & 19.3 & 18.8 & 19.0 & 19.0 & 14.5 \\
\hline Valine & 21.4 & 21.1 & 20.6 & 20.8 & 20.8 & 20.7 \\
\hline Histidine & 9.7 & 9.6 & 9.4 & 9.5 & 9.5 & 13.0 \\
\hline Phenylalanine & 20.0 & 19.7 & 19.2 & 19.4 & 19.4 & 18.1 \\
\hline \multicolumn{7}{|l|}{ Period $1-112 d$} \\
\hline Methionine & 7.4 & 7.4 & 7.4 & 7.5 & 7.5 & 9.6 \\
\hline Lysine & 25.5 & 25.7 & 25.4 & 25.1 & 25.3 & 30.8 \\
\hline Arginine & 16.6 & 16.4 & 15.9 & 16.4 & 16.2 & 15.9 \\
\hline Threonine & 18.3 & 17.9 & 18.0 & 18.4 & 18.4 & 18.8 \\
\hline Leucine & 33.4 & 32.7 & 32.2 & 33.1 & 33.5 & 32.2 \\
\hline
\end{tabular}

DM, dry matter; NRC, National Research Council.

1) Diets formulated to meet average metabolizable protein requirements. Supply of metabolizable amino acids were estimated using NRC [3] Level 1 approach, based on tabular compositional values [3] for individual feed ingredients (Table 1), and observed dry matter intake and live weight (Table 2). Metabolizable amino acid requirements were estimated based on observed average live weight and weight gain for cattle on the three-phase feeding program (Table 2) [3,4].

across treatments. This was expected, as all steers received the same non-supplemented basal diet during that 56-d period.

\section{IMPLICATIONS}

Addition of rumen-protected methionine and lysine to diets may enhance gain efficiency and dietary energetics of growing Holstein calves. Observed amino acid supply to the small intestine were in good agreement with expected, supportive of NRC [3].

\section{CONFLICT OF INTEREST}

We certify that there is no conflict of interest with any financial organization regarding the material discussed in the manuscript.

\section{REFERENCES}

1. Zinn RA, Calderon JF, Corona L, Plascencia A, Montaño MF, Torrentera N. Phase feeding strategies to meet metabolizable amino acid requirements of calf-fed Holstein steers. Prof Anim Scient 2007;23:333-9.

2. Vasconcelos JT, Galyean ML. Nutritional recommendations of feedlot consulting nutritionist: the 2007 Texas Tech University survey. J Anim Sci 2007;85:2772-81.

3. Committee of nutrient requirements of beef cattle, National Research Council. Nutrient Requirements of Beef Cattle. 7th edn. Washington, DC: National Academy of Press; 2000.

4. Zinn RA, Shen Y. An evaluation of ruminally degradable intake protein and metabolizable amino acid requirements of feedlot calves. J Anim Sci 1998;76:1280-9.

5. Hussein HS, Berger LL. Feedlot performance carcass characteristics 
of Holstein steers as affected by source of dietary protein and level of ruminally protected lysine and methionine. J Anim Sci 1995;73:3503-9.

6. Wessels RH, Titgemeyer EC, St. Jean G. Effect of amino acid supplementation on whole-body protein turnover in Holstein steers. J Anim Sci 1997;75:3066-73.

7. Committee of nutrient requirements of beef cattle, National Research Council. Nutrient Requirements of Beef Cattle. 6th edn. Washington, DC: National Academy of Press; 1984.

8. Garrett WN. Energy efficiency of beef and dairy steers. J Anim Sci 1971;32:451-6.

9. Statistical Analysis System Institute Inc. User's Guide: Statistics, version 9. SAS Inst. Cary, NC; 2004.

10. Zinn RA, Plascencia A. Interaction of whole cottonseed and supplemental fat on digestive function in cattle. J Anim Sci 1993; 71:11-7.

11. Bergen WG, Purser DB, Cline, JH. Effect of ration on the nutritive quality of rumen microbial protein. J Anim Sci 1968;27:1497501.

12. Latimer GW; AOAC International. Official Methods of Analysis of AOAC International. 17th ed. Gaithersburg, MD: AOAC International; 2000.

13. Van Soest PJ, Robertson JB, Lewis BA. Methods for dietary fiber, neutral detergent fiber, and nonstarch polysaccharides in relation to animal nutrition. J Dairy Sci 1991;74:3583-97.
14. Hill FN, Anderson DL. Comparison of metabolizable energy and productive energy determinations with growing chicks. J Nutr 1958;64:587-603.

15. Zinn RA. 1990. Influence of flake density on the comparative feeding value of steam-flaked corn for feedlot cattle. J Anim Sci 1990;68:767-75.

16. Zinn RA, Owens FN. A rapid procedure for purine measurement and its use for estimating net ruminal protein synthesis. Can J Anim Sci 1986;66:157-66.

17. Zinn RA, Alvarez EG, Montaño MF, Ramirez JE. Interaction of protein nutrition and laidlomycin on feedlot growth performance and digestive function in Holstein steers. J Anim Sci 2000;78: 1768-78.

18. Gibb DJ, Klopfenstein TJ, Britton RA, Lewis AJ. Plasma amino acid response to graded levels of escape protein. J Anim Sci 1992; 70:2885-92.

19. Klemesrud MJ, Klopfenstein TJ, Stock RA, Lewis AJ, Herold DW. Effect of dietary concentration of metabolizable lysine on finishing cattle performance. J Anim Sci 2000;78:1060-6.

20. Campbell CG, Titgemeyer EC, St-Jean G. Efficiency of D- vs L-methionine utilization by growing steers. J Anim Sci 1996; 74:2482-7.

21. Robert JC, Williams PEV. Influence of forage type on the intestinal availability of methionine from a rumen protected form. J Dairy Sci 1997;80:248. 